\title{
The Kingdom, the Power, the Glory, and the Tawdry: Neoliberal Hegemony and the "Undoing" of the Demos
}

\author{
Carl Raschke
}

This article explores Giorgio Agamben's celebrated "double paradigm of sovereignty", which introduces the Christian idea of oikonomia ("economy") as a foundational political concept in Western thinking. It argues that Agamben's far-ranging discussion improves our understanding of how Foucault's notion of biopower actually develops historically from the matrix of early Christian theology and how it becomes its own kind of "political theology" to undergird the contemporary dynamics, structure, and rhetoric of neoliberalism. Following Agamben, the argument also builds on his thesis that "economic sovereignty" today is cemented through the power of modern forms of media in much the same way that the critical theorists of the interwar period identified the "culture industry" as the genuine hegemon of capitalism. Finally, it devotes extensive attention to the work of the French social philosopher and media theorist Bernard Stiegler and his notion of "cognitive capitalism."

Giorgio Agamben; Michel Foucault; Carl Schmitt; Oikonomia; Trinity; Biopolitics; Pastorate; Karl Marx; Wendy Brown; Jean-Jacques Rousseau; Jürgen Habermas; Bernard Stiegler; Cognitive Capitalism; Neoliberalism; Social Media

Carl Raschke is Professor of Religious Studies at the University of Denver and senior editor for The Journal for Cultural and Religious Theory. His most recent books are Postmodern Theology: A Biopic (Cascade Books, 2016), Critical Theology: An Agenda for an Age of Global Crisis (IVP Academic, 2016) and Force of God: Political Theology and the Crisis of Liberal Democracy (Columbia University Press, 2015).

\section{Introduction}

The aim of this essay is to demonstrate how Giorgio Agamben's third volume of his critical trilogy on the concept of sovereignty entitled The Kingdom and the Glory: For a Theological Genealogy of Economy and Government can be read as framework for a new theory of global neoliberalism as "cognitive capitalism."1 In just the last few years a number of significant books and articles have appeared both criticizing and expanding on Agamben's argument in The Kingdom and the

1 Giorgio Agamben, The Kingdom and the Glory: For a Theological Genealogy of Economy and Government, trans. Lorenzo Chiesa and Matteo Mandarini (Stanford CA: Stanford University Press, Kindle Edition, 2011). 
Glory, while attempting to use his thesis to perform some sort of "genealogy" of the present day international order to which scholars have attached the label of "neoliberalism." The most important of these works is Dotan Leshem's The Origin of Neoliberalism: Modelling the Economy from Jesus to Foucault, a massive and extremely detailed historical investigation of Patristic theology and political theory in late Roman antiquity, which serves both to fill out and revise many of Agamben's speculations. ${ }^{2}$ Of course, the book only deals with the "origin" of neoliberalism in the first five or six centuries of the Christian era and offers no real new insights on Foucault's own contributions. A second work, which focuses more on the relationship between theological constructs and the development of early financial instruments, is Devin Singh's Divine Currency: The Theological Power of Money in the West. ${ }^{3}$ Singh's volume combines much of the Patristic literature treated by Leshem, but delves more assiduously into the kinds of innovative hypotheticals advanced by Philip Goodchild in his highly influential Theology of Money. ${ }^{4}$

But these strictly theological genealogies of "neoliberalism" do not give us anywhere near the full picture. In addition, the presumed linkage between Patristic thought and modern political economy is more a highly suggestive historical analogy for which the prestige of Agamben has set a scholarly brushfire than it is a useful map for conceptualizing the present day phenomenon. Rather than preoccupying ourselves with Agamben's notion of "economy," as the aforementioned researchers have done, we will instead inquire in this essay into the former's theory of "glory" as the secret of the present regime of virtualized political economy.

We will show through a close reading of such eminent theorists as Wendy Brown, Bernard Stiegler, and of course the Marxist tradition overall how the distinguishing feature of the relatively untheorized bogeyman of progressive politics regularly branded as "neoliberalism" is not simply capitalism gone wild. Nor is it somehow, as a number of scholars have fancifully and polemically conjectured, the inexorable millennia-long outgrowth of Western Christianity. Socalled neoliberal "rationality" has far more to do with the development of a twenty-first century symbolic economy - a global emporium of exchange built on significations and simulacra rather than surplus materiality or expropriated labor. It is this "mediatized" form of economic value that uniquely serves as the latter day architectonic for neoliberalism, which is a polity, a culture, an economy, and a structure of representation all rolled into one. Neoliberalism today has by its own internal syllogistics been the prime mover for the current "crisis of representa-

2 Dotan Leshem, The Origins of Neoliberalism: Modelling the Economy from Jesus to Foucault (New York: Columbia University Press, 2016).

3 Devin Singh / Divine Currency, The Theological Power of Money in the West (Stanford CA: Stanford University Press, 2018).

4 Philip Goodchild, Theology of Money (Durham NC: Duke University Press, 2009). 
tion", and we must do more than merely concentrate on the problem of markets and the fungibility of goods and services through historical exchange mechanisms to decipher the crisis itself.

If I may badly paraphrase Jesus, "markets you will always have with you." The dark bodings of the present neoliberal moment are to the injustice of markets what Genghis Khan was to the petty corruptions of local Byzantine officials. A much more profound and consequential set of issues are currently at stake.

\section{The Trinitarian Watershed}

In the The Kingdom and the Glory Agamben lays out in the opening sentence a project that will take Foucault's theory of "governmentality" to a new level. "This study," he writes, "will inquire into the paths by which and the reasons why power in the West has assumed the form of an oikonomia." It "locates" itself within the ongoing genealogical investigations that Foucault initiated in the 1970s, Agamben says, "but, at the same time, it also aims to understand the internal reasons why they failed to be completed." Foucault was unable, Agamben suggests, to acknowledge "the shadow that the theoretical interrogation of the present casts onto the past reaches well beyond the chronological limits that Foucault causes, as if a more primordial genetic rank would necessarily pertain to theology." In fact, it can be traced all the way back, according to Agamben, to the very "onto-theological" template for all Western thought itself, the three-in-one Godhead.

Agamben announces in his opening statement that he aims to go beyond Foucault's fixation on the clerico-confessional management of both the language and psychology of salvation compressed into the latter's notion of the "pastorate," which becomes the groundwork for the theory of "biopolitics". He argues that he wants to "show instead how the apparatus of the Trinitarian oikonomia may constitute a privileged laboratory for the observation of the working and articulation - both internal and external - of the governmental machine. For within this apparatus the elements - or the polarities - that articulate the machine appear, as it were, in their paradigmatic form." Agamben proposes a few sentences later that the question of oikonomia, which means of course "household" in Greek and from which we derive both of the terms economy and ecology, is ultimately about the essence of "power" in the Western context. The metaphysics of "economy" is, in crucial but somewhat opaque respects, paired with the seemingly "antinomical" (Agamben's term) construct of "sovereignty" in the absolute sense that Carl Schmitt analyzed in the 1920s. "The double structure of the governmental machine, which in State of Exception (2003) appeared in the correlation between auctoritas and potestas, here takes the form of the articulation between Kingdom and Government and, ultimately, interrogates the very relation - which initially was not considered - between oikonomia and Glory, between power as government and effective management, and power as ceremonial and liturgical regality, 
two aspects that have been curiously neglected by both political philosophers and political scientists."

For Agamben, both Schmitt and Foucault serve as the double axis today, much like Kant and Hegel in the nineteenth century, for an investigation of the political. In addition, the analysis of the political is impossible without consideration of its embedded theological substrata, a famous argument which Carl Schmitt advanced almost a century ago, but which has only been applied for all intents and purposes (as Agamben points out) heretofore to the notion of exceptionality (Ausnahmezustand) without due regard for the increasingly relevant concept of proportionality. This question, which perhaps amounts to a Derridean aporia or "undecidable", harks all the way back to Plato and the beginnings of Western philosophy in itself. It also trenches on the question in early Christianity of the significance of "law", or nomos, within the larger scheme of what the Greeks named dikaiosyne, or "justice". Is the law strictly situational (i.e., does it apply only, as Paul asked, to those who like the Jews are "under the law"), or is it truly "universal" in the way that Kant's "practical reason" later formulated it (i.e., valid for all persons from all cultures and polities at all times in the same set of circumstances)?

Simply stated, is "justice" ultimately retributive or distributive? And who can, or should, administer it? If justice is founded merely on sovereign, or divine, decree, then the appropriate "political" configuration is doubtlessly autocracy. If justice is all about ratio, or proportional allotment (Simonides' "rendering to each person his due" $)^{6}$, then it must subject to what contemporary theoreticians would term "administrative" or "managerial" reason - in other words, the logic of bureaucracy and the subtle play within the biopolitical venue of "power" alongside "knowledge", as Foucault understood it. ${ }^{7}$ The latter would also be the prevailing semiotic coding mechanism for present day democracies. How does one, therefore, assess real, as opposed to imagined, power in accordance with the paradigm of "governmentality" that Foucault initially sketched out? And what would be the theological episteme, as Foucault might call it, within which this process unfolds?

Agamben notably argues that the paradigms of both sovereignty and oikonomia derive straightaway from "Christian theology" - on the one hand, a "political theology, which founds the transcendence of sovereign power on the single God," and on the other hand, an "economic theology, replacing this transcendence with the idea of an oikonomia, conceived as an immanent ordering domestic and not political in a strict sense - of both divine and human life." ${ }^{8}$ The theological provenance of both transcendent sovereignty and an "immanent or-

\footnotetext{
5 Agamben, The Kingdom and the Glory, loc. 113-119.

6 Plato, Republic, 331(e).

7 See Michel Foucault, Power/Knowledge: Selected Interviews And Other Writings (New York: Vintage, 1980).

8 Agamben, The Kingdom and the Glory, loc. 150-156.
} 
dering" is the Trinitarian formulation at Nicea. Trinitarianism historically can be seen as a compromise to reconcile the Caesaro-papal instincts of Christianity's new imperial benefactor Constantine, who sought to unify the empire under one common faith, with the "pastoral" apparatus that the underground and previously persecuted church had already achieved with its remarkable, organizational prowess over nearly three centuries. The Trinitarian formula was also a sophisticated outworking in both a political and philosophical context of the inherent "incarnational" synthesis of pagan and Jewish thought brilliantly articulated from 50 to approximately 65 A.D. by the apostle Paul. Apart from such a synthesis, Christianity would not only have failed to develop over time, especially after the debacle of the Jewish War in 70 A.D. It would also have proved inadequate as a true "state religion" designed to hold the fractious and centrifugal forces of a decaying Roman empire together, a project which a successive caesars prior to Constantine had unsuccessfully attempted under the guise of an innovative form of unitary "solar monothesism". ${ }^{9}$ The prestige of the militarized Roman state had already been in decline since the disasters on the frontiers a century earlier. Hence, Constantine needed a new, religio-symbolic order that embraced the pieties of the already sprawling and largely literate clerical classes, which were heavily populated by Christians. The Christianity of antiquity from the outset was what Foucault terms "governmental", and it came to be secularized, especially in the France of the seventeenth and eighteenth centuries as well as Prussia during the nineteenth century, which invented through the ministrations of the Lutheran Landeskirche what has come to be known as "state socialism". Genealogically, the Prussian prototype of a secularized clerical state governance centered on the university and its "faculties" along with the military and a cartelized financial system dating all the way back to the Middle Ages was the seedbed for the growth of what currently we recognized as larger "neoliberal" order, not to mention Bernard Stiegler's "cognitive capitalism" or Peter Drucker's "knowledge society."

\section{From Oikonomia to Biopolitics}

So far as Agamben is concerned, the "biopolitical" administration of the world is authorized by the idea that the divine is, in effect, a triple functionary, as first enunciated per scholarly consensus by the church father Irenaeus of Lyon in the latter half of the second century with his claim that the Godhead is one in reality, but manifests through three different functions, or operations. ${ }^{10}$ Whereas Irenaeus

9 See James B. Rives, Religion in the Roman Empire (Hoboken NJ: Wiley-Blackwell, 2006) as well as Andrew Cain, The Power of Religion in Late Antiquity (New York: Routledge, 2009).

10 Jackson J. Lashier, however, in his close reading of Irenaeus' works suggest that 
understands the "economic" administration of the Triune God to entail the work of the Son as well as the Father and the Spirit, Agamben is concerned mainly with the first and third persons of the Trinity. But what makes oikonomia unique, according to Agamben, is that it mirrors not the sphere of sovereignty that informs the politeia (that is, "the political") but the household. Broadly conceived, oikonomia in the Aristotelian setting has only to do with the conduct of personal or family affairs - dealings between master and slave, father and children, husband and wife - which are completely set apart from, and impenetrable by, the polis. Whereas in the modern "republican", or bourgeois, setting the household would be regarded as a kind of monadic prototype for civil society - and in Hegel's "philosophy of right" for the rationality of the state tout court - it would paradoxically in the Athenian environment be envisioned as the very penumbra of the political. How would, therefore, the "economic" model of human relationships be gradually given separate, but importance with "despotic" sovereignty? The result would be a Christian "political theology" that would ultimately leave its unmistakable "signature", as Agamben puts it, on the modern secular order, while perhaps becoming what Schmitt in his later work would describe as the "nomos of the earth"?

It is a commonplace among historians that the Christian ekklesia evolved during and throughout the pre-Constantian era as a kind of shadow state, purposed for the general "care of souls", filling an enormous social as well as spiritual vacuum which the militarized and overly politicized imperium was completely derelict in executing. The role of the Christian pastorate, therefore, became its own kind of Aristotelian "household" writ large and inscribed, despite the recurrent antagonism of the imperial authorities, within the "cosmopolitan" expanse of an increasingly unwieldy - and ungovernable - empire. After the "conversion" of Constantine, the dialectics throughout the Mediterranean world of polis versus oikonimia resulted in an unparalleled moment of Aufhebung, which still persists into the present.

At the same time, if "politics" and "economics" are now separate, yet theoretically inseparable, in the guise of what we have come to call "political economy", and if these two modalities of "administration" have been fused ever since the age of Constantine by a dominant political theology of both God and government as necessarily sovereign, yet simultaneously "caring" and concerned for the general welfare, what does that portend for the present and evolving "globalist" configuration of polities and peoples, one in which once independent ethnicities, the pith of national sovereignty ever since the seventeenth century, have been replaced with the new transnational empire of fluid markets and nomadic

Irenaeus was not the first to articulate an "economic" model, but drew on various threads of commentary from an earlier generation of Christian apologists. See Jackson J. Lashier, The Trinitarian Theology of Irenaeus of Lyons, unpublished doctoral dissertation, Marquette University, May 2011. 
capital? This new empire is no longer defined by disciplinary structures of hegemony and authority as much as by the swarming and "sliding" signifiers (in Lacan's sense) that constitute digital communications and the infinitely rarified specimens of financial transactivity? Such indicators, following the academic conventions of the last decade or so, delineate much of what has come to be known as "neoliberalism." And the new planetary regime that carries its name has come to be invested with a certain disrepute, even among those who are visibly as well as invisibly its agents of influence and benefactors.

At a very superficial level, this new global demesne of etherealized capital, which as we have seen derives its power from the pseudo-ethical imperative of a "socially conscious" consumerism that will "save the planet", resembles the ancient ideal of Romanitas. Such an ideal can be summed up simply as collection of higher "humanist" values on which citizens of the empire relied in order to justify morally and culturally their brutal subjugation of the far-flung multitudes. It was similar to the British colonizer's fiction of their "civilizing mission" throughout the nineteenth century. But this kind of "humanism," which the Romans invariably contrasted with the pervasive "barbarism" which they were convinced had to be conquered and pushed back from its borders, was ultimately inadequate to keep the empire together. It inexorably fell prey to a kind of regional warlordism stoked by the increasing reliance of the regime on non-citizens, or what today we would describe as "stateless" mercenaries, to maintain peace and order amidst a widely dysfunctional political, as well as steadily collapsing economic, system.

What the Christian oikonomia provided was a different form of governance akin to what today we would call "soft power" through the mediation of a compelling new symbolic ensemble of instrumentalities. In Agamben's view the power wielded by the "pastorate" in this new clerical economy derives from what he calls a politics of "glory." Such a politics is immanently inscribed within the social order to the extent that it encompasses the entirety of those who are not mere subjects, but also those who are claimed by, or theorized as coming under the authority, of the lordly realm. The Medieval legal figment of a "Holy Roman empire" could not have been elaborated over the centuries without this curious sort of pastoral postulate. In Roman times this privilege of invoking such a principle was accorded only to the narrow circle of those holding "citizenship". But the early church rendered it "transcendental" in the sense that it promoted a novel style of "subjectivity" through baptism into, and participation within, the body of Christ. In other words, because of the pastoral postulate Christians were constituted as more than simply political subjects. They were incorporated soteriologically, rather than strictly civically, into a "kingdom not of this world." 


\section{The Instrumentality of Glory and the Origins of a Symbolic Economy}

Augustine, writing during the decades of imperial prostration in the early fifth century, first laid out the general theory of such dual subjecthood in his City of God. But while he, like Paul, looked for the reconciliation of these "two kingdoms" only at the moment of an eschatological finale, his ecclesiastical imagination laid the groundwork for the revival of the Constantinian synthesis during the high Middle Ages and eventually for the rise of a novum ordo seclorumn in the late modern period. The question of "glory" as "the uncertain zone in which acclamations, ceremonies, liturgies, and insignia operate", for Agamben, came to be transposed from the sacerdotal to the symbology of secular politics overall. ${ }^{11}$

Agamben writes: "glory is the place where theology attempts to think the difficult conciliation between immanent trinity and economic trinity, theologia and oikonomia, being and praxis, God in himself and God for us. For this reason, the doxology, despite its apparent ceremonial fixity, is the most dialectical part of theology, in which what can only be thought of as separate must attain unity." 12 The instrumentality of "glory," which was used routinely by both kings and clergy up until early twentieth century and became the flash point for the kind of sectarian conflict that eventually morphed into anti-clerical political revolutions, served as the precursor, according to Agamben, for the aestheticization of mass politics that found its most demonic expression in the various totalitarianisms of the twentieth century. "We find here, as we find at the hidden root of all aestheticisms," Agamben notes, "the need to cover and dignify what is in itself pure force and domination". ${ }^{13}$ But this "aesthetic" subterfuge can also be understood in terms of the virtualization of politics through both earlier and later forms of media and the manipulation of what once were material interests through the idealizing mechanisms of a "symbolic economies," about which I have written in my book Force of God. ${ }^{14}$

The idea of a purely symbolic economy was advanced during the 1970 s by a lesser known French post-structuralist theorist named Jean-Joseph Goux, roughly about the same time as Foucault began his decade of lectures at the College de France. It is Goux's overarching approach, adapted from Marx's analysis of the fetishism of commodities in Book I of Capital as the generative principle in the formation of surplus value, that helps us frame a broader theory of neoliberalism as global governance by purely semiotic operators. These operators, or "signifiers", are not so much a cover for "pure force and domination" as they are they are the

11 Agamben, The Kingdom and the Glory, loc. 3917.

12 Agamben, The Kingdom and the Glory, loc. 4316.

13 Agamben, The Kingdom and the Glory, loc. 4385.

14 See Carl Raschke, Force of God (New York: Columbia University Press, 2015), especially pp. 73-77. 
force of domination itself. Goux relies on Marx's observations about how commodification serves as an anticipation of the ultimate epiphany of alienated labor under the aspect of money. Political economy, not only for Marx but for a number of his predecessors, comes down to the issue of how value is created. In Marx's final analysis, such value constitutes different transmutations, or "crystallizations", of labor as commodities, culminating in their "dazzling money form."15 Commodification progresses through the increasingly obscure alchemy of the market exchange mechanism. In order for commodities to be exchanged, their "values" must be compared by some kind of rational set of criteria. But the commodities themselves cannot serve as a basis of comparison. Their values are merely "relative" to each other.

Thus there must emerge a general principle for comparing the relative values of commodities, a "value of values", so to speak, or what political economy designates as a "general equivalent". The brandishing of the general equivalent requires that we excise the value of the labor that went into making it, yielding a more recondite form of value containing nothing more than "abstract labor." Marx writes that "the body of the commodity that serves as the equivalent, figures as the materialisation of human labour in the abstract, and is at the same time the product of some specifically useful concrete labour." ${ }^{16}$ The money form of the commodity becomes the very prima materia for the accumulation of "surplus" labor value (Mehrwert) from which all historical variants of "capitalism" spring. The general equivalent, or the "money form," thereby becomes the sorcerer's apprentice that sets in motion an endless procession of formal correlations ("simulacra," as Jean Baudrillard calls them), converting material inputs into immaterial regalia. This "virtualization" of concrete value through commodity production, especially in the money form, is also the occasion for class conflict and exploitation, so far as Marx is concerned.

Marx, of course, in his fidelity to Hegelian dialectics believed that this process over time would bring about the ripening of multiple, inherent "contradictions" in the system, leading to its eventual breakdown and the onset of revolution. But what Marx did not foresee was the way in which the virtualization process itself, including what Maurizzio Lazzarato terms "immaterial labor", could be further virtualized and consequently commodified, bringing into being the brave new world of today where "knowledge" is not a simple condition for the manufacture of usable "things," but a thing to be produced and valued for itself, which is what we really have in mind when we prattle on about "knowledge workers" and the "knowledge society."17

\section{Karl Marx, Capital, Book 1, 6.}

16 Marx, Capital, Book 1, 11.

17 Lazzarato writes: "The 'great transformation' that began at the start of the 1970s has changed the very terms in which the question is posed. Manual labor is increasingly coming to involve procedures that could be defined as 'intellectual,' and the new com- 
Goux explains how this kind of transformation takes place: "instead of the relation, in which symbolicity is constituted; instead of exchange, through which subjects, in partially reversible fabric, can metabolize the signifiers that constitute them - the symbolic freezes into a rigid mediation that dominates them. Furthermore, if the symbolic relations introduces a third entity, a mediating element, by which the ceaseless floods of the imaginary are absorbed ... a symbolic counteraction, operating like a forced currency, blocks the balancing process and dispossess subjects of their own activity, through the symbolic functions of the state, money, the concept." 18 Thus the contemporary "crisis of representation" can be understood as fundamental to the very translation of politeia into oikonomia, or at least the beginning of a recognition that they are interchangeable somehow at an ontological level. The introduction of the primordial intuition of value as "exchange value", which defines the "economic" paradigm as a whole, demands this shift in our perception.

\section{The Neoliberal Moment}

Nevertheless, it is not only money that presents itself as the new face of tyranny in serving to "dispossess" subjects of what is properly their own through the apparatus of symbolization, virtualization, and de-materialization. If the virtualization of finance had a lot to do, as most analysts agree, with the Great Recession that started in the fall of 2008, the digitization and proliferation of personalized media has been a driving force in the degeneration of politics into low-grade civil war. Standard critiques of neoliberalism, especially since the instant media sensation that came to be known as the Occupy movement in September 2011, have focused on the heightened maldistribution of wealth and traced the current malaise to a revival of a predatory capitalism not seen since the 1890s. But a more recent wave

munications technologies increasingly require subjectivities that are rich in knowledge. It is not simply that intellectual labor has become subjected to the norms of capitalist production. What has happened is that a new 'mass intellectuality' has come into being, created out of a combination of the demands of capitalist production and the forms of 'self-valorization' that the struggle against work has produced. The old dichotomy between 'mental and manual labor,' or between 'material labor and immaterial labor,' risks failing to grasp the new nature of productive activity, which takes this separation on board and transforms it. The split between conception and execution, between labor and creativity, between author and audience, is simultaneously transcended within the 'labor process' and reimposed as political command within the 'process of valorization."' Maurizio Lazzarato, "Immaterial Labor", in: Radical Thought in Italy: A Potential Politics, ed. Paolo Virno and Michael Hardt (Minneapolis MN: University of Minnesota Press, 2006), 133.

18 Jean-Joseph Goux, Symbolic Economies: After Marx and Freud (Ithaca, NY: Columbia University Press, 1990), 163. 
of literature has focused on the hegemony of the symbolic economy itself. Many of these writers have drawn attention to the co-dependency of such an economy with what we might term consumptive consumerism. Wendy Brown, perhaps foremost among such theorists, characterizes the way in which these symbolic economies expropriate not only a person's labor, but their very value and self-worth. They force us to become "entrepreneurs of the self", an expression coined by Foucault which Brown leverages extensively in her argument that neoliberalism transforms everything into capital, especially the kind of "personal capital" that thoroughly reconstitutes individual self-worth as professional identity in keeping with socially enforced criteria of symbolic comparison. Brown writes:

"The figure of the human as an ensemble of entrepreneurial and investment capital is evident on every college and job application, every package of study strategies, every exercise, every new diet and exercise program. The best university scholars are characterized as entrepreneurial and investment savvy, not simply by obtaining grants or fellowships, but by generating new projects and publications from old research, calculating publication and presentation venues, and circulating themselves and their work according to what will advance their value."19

At the same time, what these strategies of both cultural and economic analysis, which prove to be intimately intertwined when it comes to the critique of neoliberalism, tend to miss is the determinative role of media. As the pioneers of critical theory within the so-called Frankfurt School during the first half of the twentieth century realized, the "holy alliance" of culture and capital, which achieves its Gramscian-style synthesis in the evolving figurations of social control through not only mass media platforms but also individualized digital communication, is the real dark matter that needs to be illuminated by the light of reason. The politics of mediatization need to be reviewed in light of the mediatization of politics, and that is where Agamben's claim that modern communications provides an aura of "glory" for democratic politics, where pomp and pageantry no longer suffice, turns out to be suggestive, even while it remains rather obscure. According to Agamben, Schmitt's rule that politics rests on a monarchial declaration of sovereignty - or at least a constant condition of inimicality (the "friend/ enemy distinction") analogous to the state of exception - only works within an autocratic setting.

Rousseau's notion that sovereignty in a formal sense can also be engraved within the demos is not necessarily compatible with Schmitt's deduction of political power. Likewise, Rousseau's contention that democratic sovereignty has a historical warrant, insofar as it invokes contra Hobbes a certain commensurability of the political with life the state of nature ("man is born free, but everywhere he is

19 Wendy Brown, Undoing the Demos: Neoliberalism's Stealth Revolution (New York: Zone Books, 2015), 36-37. 
in chains"), presses us toward accepting the "economic" model of governance. Such a move is consistent with the kind of providential calculus concerning the rise and fall of human societies implied in Adam Smith's metaphor of the "invisible hand", and it constitutes an epochal shift in the rudimentary representation of "political economy" as a whole.

Agamben perhaps takes Rousseau further than he would have otherwise been willing to go. One of the essential tensions in the eighteenth century theory of the social contract turns out to be tug-of-war between the ideal of collective cohesion founded in the "general will" and the need for some kind of transcendental legitimation of democratic sovereignty. With the latter goal in mind, Rousseau came up with the heuristics of a "civil religion." Rousseau's formulation of such a civil religion can be found toward the close of The Social Contract: "there is therefore a purely civil profession of faith of which the Sovereign should fix the articles, not exactly as religious dogmas, but as social sentiments without which a man cannot be a good citizen or a faithful subject." ${ }^{20}$ These "social sentiments" can only be buttressed by the weight of the symbolic. The potency of the symbolic, or what Agamben terms "glory", has its avatars in the era of democratic egalitarianism with what Guy Debord famously named the "society of the spectacle." Agamben writes that:

"If we link Debord's analysis with Schmitt's thesis according to which public opinion is the modern form of acclamation, the entire problem of the contemporary spectacle of media domination over all areas of social life assumes a new over all areas of social life assumes a new guise. What is in question is nothing less than a new and unheard of concentration, multiplication, and dissemination of the function of glory as the center of the political system. What was confined to the spheres of liturgy and ceremonials has become concentrated in the media and, at the same time, through them it spreads and penetrates at each moment into every area of society, both public and private. Contemporary democracy is a democracy that is entirely founded upon glory, that is, on the efficacy of acclamation, multiplied and disseminated by the media beyond all imagination. (That the Greek term for glory - doxa - is the same term that today designates public opinion is, from this standpoint, something more than a coincidence.) As had always been the case in profane and ecclesiastical liturgies, this supposedly "originary democratic phenomenon" is once again caught, orientated, and manipulated in the forms and according to the strategies of spectacular power." ${ }^{21}$

It is not entirely clear what Agamben has in mind with this analogy with the phrase "efficacy of acclamation." The analogy with regal pomp and circumstance implies that the media somehow manages only to lionize, and thereby legitimate, the

20 Jean-Jacques Rousseau, The Works of Jean-Jacques Rousseau: The Social Contract, Confessions, Emile, and Other Essays (Baltimore MD: Common Knowledge Publishers, 2004), Kindle Edition, loc. 1592-1596.

21 Agamben, The Kingdom and the Glory, loc. 5288-98. 
formation of sovereignty within the modern demos. However, it becomes immediately apparent, once we read just a little further in this concluding reflection of Agamben's The Kingdom and the Glory, which admittedly is not as developed or well-formed as it should be, that he is alluding to Jürgen Habermas' theory of "communicative action." Habermas' recipe for democracy as founded on the inherent rationality of communicative, or deliberative, power is well-known. As Habermas declares in Between Facts and Norms (1996), "all political power derives from the communicative power of citizens." 22

Habermas grounds this assertion in what he dubs an "illocutionary" construct of rationality - something akin to, more "Platonist" in its origins, to what Derrida came to call the "New Enlightenment" - "when language is conceived as universal medium for embodying reason." 23 The maintenance of linguistic coherence as a "postmodern" version of the classic political logos, resident within the systems or communicative transaction and symbolic exchange comprising the new cosmopolitan agora, fosters in our present day "lifeworld" (to invoke Habermas' own expression) the conditions for both democratic participation and the commitment of citizens to some form of the "common" or "public" good. For Agamben, this preservation of Habermas' "knowledge-constitutive interests" through the cultivation of a pluralized, yet intelligible fabric of shared discourse is not, however, to be established pragmatically through the intervention of the academic disciplines, especially philosophy. Such a higher, governmental role for "critical theory" was always the aspiration of the Frankfurt School, and can perhaps be traced all the way back to Plato's own call for rule by "philosopher kings." It can, at least, be linked to some of the inclinations of Frederick the Great during the eighteenth century in his dream of a Europe commandeered by "enlightened despots". Frederick sought to replace the hegemony of the clergy with that of professors, an episode in the evolution of the social imaginary that inspired to a certain degree the founding of the Prussian state system of universal education, which would indirectly nurture a "virtuous" citizenry.

The "glory" of the democratic and "holistic" state in the view of Agamben is "founded on the immediate presence of the acclaiming people, and the neutralized state that resolves itself in the communicative forms without subject, are opposed only in appearance. They are nothing but two sides of the same glorious apparatus in its two forms: the immediate and subjective glory of the acclaiming people and the mediatic and objective glory of social communication." ${ }^{24}$ According to Agamben, "glory" in this regard demonstrates "its dual aspect, divine

22 Jürgen Habermas, Between Facts and Norms: Contributions to a Discourse Theory of Law and Democracy, tr. William Rehg (Cambridge, MA: MIT Press, 1996), 170. See also Jeffrey Flynn, "Communicative Power in Habermas' Theory of Democracy", in: European Journal of Political Theory 3(4): 434.

23 Habermas, Between Facts and Norms, 8.

24 Agamben, The Kingdom and the Glory, loc. 5332. 
and human, ontological and economic, of the Father and the Son." Following Habermas' distinction, it can be construed as mediating both "the people-substance and the people-communication." 25

\section{Bernard Stiegler's New Critique of Political Economy}

But what if Agamben were dead wrong, and what if his notion of mediatic "glory" has metasized, as we are seeing increasingly nowadays, turned out instead to be the tawdry? What if this "tawdriness" were in fact the inevitable "cash-out" of the symbolic economy itself, of an appalling, but spectacular climax to the ongoing virtualization of both labor and capital in a latter day, gargantuan immolation of both meaning and signification whereby the "crisis of representation" becomes a global catastrophe of the political itself? What if the linguistics of "communicative reason" had now morphed as in some kind of insidious mutation of its own semiotic genomes into a hyperpartisan "hate machine?" How could that even happen? In order to answer that question, we must begin to pay heed to Bernard Stiegler's urgent call for a "new critique of political economy" that understands the linguistic process in keeping with both Plato's and Derrida's reading pharmakon, as both "poison and remedy." Stiegler's brilliant analysis of the problem, published in 2010 at a time when the current sordid state of politics was lamentably but a small, lowering cloud on the horizon, calls into question the very sentimental assumptions about the connections between democracy, discourse, rationality, and mediatic expression, which Agamben together with Habermas have dangled in front of us. "We thus have pure cognitive labor power utterly devoid of knowledge with cognitive technologies, Stiegler writes"26. "The cognitive elites" are "deprived of their own logic and by their logic- a logic reduced to a calculation without remainder as well as to a market of fools." ${ }^{27}$

In order to achieve a better grasp of what Stiegler intends with such a comment, we need to flesh out his larger perspective. For A Critique of Political Economy pulls together many of the threads of his extensive, earlier writings to revive a call for a critique of capitalism in the twenty-first century that takes up from what Marx left undone in the nineteenth century. Stiegler set forth these remarks in the immediate wake of the worldwide economic crisis that began in the fall of 2008, but became manifest in 2009. In the first chapter entitled "Heads Buried in the Sand: A Warning," Stiegler makes the case that both the Keynesian "stimulus" to what was supposed to have engineered recovery from the Great Recession and the digital automation of industry that is proceeding apace "is the translation of a

25 Ibid.

26 Bernard Stiegler, For A New Critique of Political Economy, trans. David Ross (New York: Polity, 2010), 46.

27 Stiegler, For A New Critique of Political Economy, 47. 
moribund ideology, desperately trying to prolong the life of a model which has become self-destructive." 28 At the same time, Stiegler is not merely advancing some cheap, hackneyed version of rhetoric against capitalism per se. It is the distinctive new kind of capitalism - i.e., "cognitive capitalism" - that is bringing the crisis to a head. Cognitive capitalism constitutes an economic as well as a social apocalypse of the virtualization process, the beginnings of which antedate electronic media by two and a half millennia. The overarching philosophical dilemma we have dubbed the "crisis of representation" is centered on the technical issue of hypomnesis, or the exteriorization of memory, Plato identified in the Phaedrus as the danger posed by writing. Plato's preoccupation was the loss of direct access to the real, a position Derrida in Of Grammatology characterized as "ontotheological".

Writing, Plato insists in the latter section of the Phaedrus, is anti-philosophical

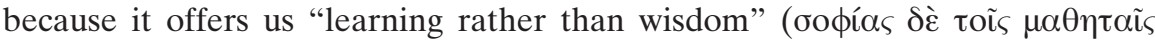
$\delta o ́ \xi \alpha v)^{29}$, and philosophy is of course the pursuit of the latter. Such "learning" is mere "semblance" (doxa), and even though it provides expanding opportunities for the elaboration of new discursive connections, it fosters an amnesia of the thing itself, as Heidegger was fond of pointing out, through the production of incessant re-presentations (or if we wish instead to use Baudrillard's terminology, we can say the "precession of simulacra". Such re-presentations are, if we want to use a current cliché, a form of "fake presence." And it is "presence", or ousia, in the Platonic tradition that constitutes the authentic object sought through philosophical inquiry. Stiegler, a student of Derrida who in turn criticized the Socratic discomfort with writing as a "potion" (pharmakon) that simultaneously "poisons" the well of wisdom while "remedying" the affliction of forgetfulness ironically seems to side with Plato. But his Platonic sympathies have little to do with a preference for ontology. The crisis of representation derives from the manner in which "learning" (mathesis), or the spatio-temporal coding and archiving of what was once knowledge by acquaintance, comes to reify the hypomnetic process as the human essence itself.

Thus the invention of "writing," which by Stiegler's reckoning is but a convenient trope for hypomnesis as a whole encompassing everything from symbolic logic to electronic bits and bytes, sets in motion an historical juggernaut careening toward a "transhuman" future. Hypomnesis is what we really mean by "capital" as a rendering of Marx's "alienated labor", and it threatens to eclipse us all as "artificially" intelligent machines that not only eliminate jobs, but even human intimacy (think the latest, uncannily human "sexbots" that are creeping into the market). The difference between "wisdom" (sophia) and "learning", or "science" (mathesis), is what Stiegler calls savoir faire versus savoir vivre. Science and technology furnish only "know-how" (savoir-faire), engendered from experiences

\footnotetext{
28 Stiegler, For A New Critique of Political Economy, 4.

29 Plato, Phaedrus, 275a.
} 
brought about through manipulation of the human environment using symbolic tokens and apparatuses.

Relying on terminology harking back to Edmund Husserl, Stiegler refers to this mode of sign-production as "tertiary retention." Tertiary retention is the key to hypoamnesis, because it gives impetus to a wider process Stiegler dubs "grammatization," a convoluted but inexorable and irrepressible historical movement for which the development of writing is only the first instantiation. In other words, grammatization, which encompasses everything from manuscripts and their dissemination to the even more sophisticated use of numbers and formal protocols for ciphering equivalencies to abstract reasoning on the part of both homo sapiens and computing machinery, consists in the commodification of truth itself. The commodification of labor, as Marx understood it, is merely one moment in the unfolding of a much greater and consequential trendline. "Alienated labor" is simply a harbinger of the eventual extinction of what it means to be human, which relies on savoir vivre, "knowing how to live." A genuine "critique of political economy," for Stiegler, cannot be separated from the critique of human knowledge overall.

Stiegler insists that this extreme stage of alienation conceals a genuine crisis of capitalism. We might add that it appears as well to be the watermark of neoliberalism itself. "The capitalist economy strictly speaking no longer works," Stiegler contends, "because it wants the psychic individualism to be self-detected, to become the 'entrepreneur of the self', without collective individuation, but rather through a collective disindividuation orchestrated by marketing," which Stiegler writes includes both the so-called "conservative revolution" of 1980s and the present post-millennial phase of global, corporate neoliberalism. ${ }^{30}$ The notion that contemporary culture is a form of self-entrepreneurship whereby our alienated self-knowledge now becomes a kind of high-octane fuel that powers the capacious neoliberal modus operandi, of course, can be attributed to Brown in her Undoing the Demos. Brown is the first to recognize that neoliberalism is not merely a tendentious set of economic principles, but "a form of normative reason remaking the state, society, and subject, generating social policy, positing truth and a theory of law." It is, in effect, "a revolutionary and comprehensive political rationality, one that draw on classical liberal language and concerns while inverting many of liberalism's purpose and channels of accountability." 31 Brown stresses that neoliberalism subtly stands on its head the classical liberal values emphasizing personal freedom by summoning such grandiloquence to perform the task of constraining the social agent to the unfreedom of self-entrepreneurship in the name of the vast, collective good - what she terms "responsibilism." Responsibilism never prescribes an objective, person, or idea to which is nevertheless always "responsible." One can never do enough, because there is always infinitely

30 Stiegler, For A New Critique of Political Economy, 61-62.

31 Brown, Undoing the Demos, 69. 
more to do. Responsibility is unbounded; it is forever committed to an imperceptible "elsewhere."

\section{Cognitive Capitalism and the Crisis of Neoliberal Hegemony}

The idolatry of cognitive capitalism, which seduces both of our instincts for selfvalidation and helping others, is founded on an ethic of "knowledge, thought, and training" that are "valued and desired for their contribution of capital enhancement." ${ }^{32}$ It should be noted that contrary to latter day sentimentality of today's "Bohemian bourgeoisie" that is fond of parroting Marxist slogans from the cubicle of a tech firm offering exorbitant salaries and benefits, or from the comfort of an oak-paneled university office where "revolutionary" ideology is not matched by the commitment to taking authentic political risks, the real neoliberal power complex is no longer vested in the likes of neither Ebenezer Scrooge, the Koch Brothers, nor even the legendary "military industrial complex". Instead it accrues to the captains of the new "knowledge industries", allied with intelligence agencies and vast, government bureaucracies, who leverage the infrastructure of electronic communications networks more and more to manage and regulate the contents of information flow and their formatting into usable snippets of insight. The new planetary space of cognitive capitalism (it is actually, he insinuates rather cryptically a type of "mafia capitalism"), according to Stiegler, becomes a vast desert of "pure calculable exchange" wearing the deceptive mask of "socially conscious" enterprise. It becomes a type of transnational, postmodern, postChristian secular "supergo", as Emmett Rensin has called it ${ }^{33}$, that exploits in its own unique style the consumerist "will to nothingness," as Nietzsche would have described it.

Stiegler is not, however, an unrepentant pessimist. Like Marx, he offers his own eschatological vision, which we will explore in some of the passages that follow. But what is missing in Stiegler - and to a large degree in the growing chorus of critics as well as diagnosticians of the deeper "logic" of neoliberalism - is the way in which this novel type of "political rationality" is driven by and large by mediatization itself. In other words, how does Agamben's mediatic "glory" alchemize into the basest illustration of the "tawdry"? In order to answer that question, we must examine another core concept of Stiegler's, what he in a very plain-spoken manner identifies as "stupidity" (bêtise) $)^{34}$.

\section{Brown, Undoing the Demos, 177.}

33 Emmett Rensin, The Blathering Superego at the End of History.

34 The French word bêtise, which Stiegler strategically employs, can also be translated as "brutishness", "senselessness", or even "foolishness", depending on the context. Stiegler wants to drive home that is a condition of the late modern era that does not call in an obvious sense for moral opprobrium, but is a kind of fatuousness that can precipitate 
Stiegler views his calling as a renewal of the task defined by Horkheimer and Adorno in The Dialectic of Enlightenment and detailed at the height of the Second World War, that of courageously investigating how the Age of Reason had metastasized into the pseudo-politics of totalitarianism, where "public life has reached a state in which thought is being turned inescapably into a commodity and language into celebration of the commodity." 35 The commodification of thought and language, for Stiegler, is far more complicated than what the Frankfurt School interpreted as the descent of reason into unreason, the "reversion" of logos to mythos, as manipulated cunningly through fascist propaganda. It is the baleful outcome of the triumph in all spheres of hypomnesic technology and its very "interiorization" in both conscious and unconscious life. "What is occurring, on a scale and in conditions that were hitherto inconceivable," Stiegler writes, "is the effect of what Gramsci described as a cultural hegemony that de-forms reason reason understood in Enlightenment terms as that historical and social conquest that now seems to decompose so rapidly into rationalization." ${ }^{\text {"36 }}$

In his Prison Writings from 1929-35 Gramsci himself had foreseen this evolution with his observation that Hegel's "ethical state" as the embodiment of moral and cultural reason (favored by liberal democrats) had fallen victim to the same kind of "fetishism" that Marx ascribed to the logic of commodification. This fetishism marks usurpation of what Gramsci called the "philosophy of praxis" by the cultural and linguistic apparatus exercised through popular communication techniques appropriated by the rising class. Writing at that juncture in the history of Europe when fascism had supplanted class consciousness with what the Frankfurt School had recognized as a hostile takeover of the collective unconscious under the sway of the "culture industry", Gramsci discerned that hegemonic relations in twentieth century society were neither political nor economic so much as they were semiotic. In that respect Gramsci was the one, long before Stiegler, to cognize how any "revolutionary" seizure of the means of production could not be separated from the means of culture production. Moreover, such a

ghastly results, as implied in Hannah Arendt's celebrated expression "the banality of evil." Stiegler draws to a certain extent on Derrida's critique of Agamben in his final lecture series around the question of "what lives?", where the totalitarian politics of "bare life" profiled by Agamben in Homo Sacer is re-imagined as the transformation of the politics of experience (savoir vivre) into an automatism of the abstracted subject, where "living" (vivant) substance becomes an empty "set with no other unity." See Jacques Derrida, The Beast and the Sovereign, trans. Geoffrey Bennington, vol. ii (Chicago: University of Chicago Press, 2011), 8.

35 Max Horkheimer and Theodor W. Adorno, Dialectic of Enlightenment. Philosophical Fragments, trans. Edmund Jephcott (Stanford CA: Stanford University Press, 2002), xiv.

36 Bernard Stiegler, States of Shock: Stupidity and Knowledge in the 21st Century (Hoboken NJ: Wiley Blackwell, 2015), Kindle edition, loc. 817-820). 
seizure, if it were possible at all, would have to depend on a new kind of communicative internationale, who through a universal dictatorship of the cognitive proletariat would would upend the system of semiotic control in accordance with which Foucaultean biopower resolves itself into the most insidious subterfuges of logopower. "Every relationship of "hegemony", Gramsci contends, "is necessarily an educational relationship and occurs not only within a nation, between the various forces that comprise it [...] in the entire international and world field." ${ }^{37}$

It is significant that Gramsci alluded in his notebooks to the emerging hegemonic role of journalism, which he characterized as a contingent of "pocketgeniuses", which pretends to be "holding the whole of history in the palm of its hand." ${ }^{38}$ But Gramsci was naturally unable to anticipate the digitization of both news and entertainment media where the "manufacture of consent" was boosted exponentially by an explosion, if not the amalgamation, of digital communication and commerce, especially what we now know as "social media". In social media Stiegler's "tertiary retention" desiccates not only lived experience, but the spiritual fabric of human relationships, an electronic bellum omnium contra omnes that has become the strange and eminently hostile "twittering" virtual universe we know as politics in this day and age. The demos that has been "undone" by this global apotheosis of grammatization and mediatization (by a proliferation of not only "fake news" but "fake agencies" of the electronic sort that cull, peddle, and feature what we are supposed to know through marketizing algorithms and hyperbots that exercise their own seamless, yet invisible control over the new "symbolic milieu" (Stiegler).

Stiegler himself calls for an insurrection against this pervasive alien dominion of a machinic "deep state" that might be fomented somehow through a recovery of the intimacy of wisdom itself, the wisdom of the body, of classical mnemosyne, of philosophy as the philia of sophia, something akin to Alain Badiou's notion of love itself as a revolutionary praxis, or "truth procedure." Such an insurrection requires the severance, according to Stiegler, of "the interface between the technical system and social systems" and the "economic system." The upshot would be what he calls l'économie de contribution ("the economy of contribution"), which unfortunately he does not specify in any detail. Knowledge must be valued for its own sake, or at least for social flourishing. Such a society would be anti-consumerist. In an interview with a representative of the Macif Foundation, Stiegler comments:

"This model [of the society of contribution] rests on investment and citizens taking responsibility. It differs from Fordism because it depends on de-prolaterisation (sic). For Marx, the workers are proletarized when their expertise is replaced by the machines that

37 Antonio Gramsci, Further Selections From The Prison Notebooks (Minneapolis MN: University of Minnesota Press, 2015) Kindle edition, loc. 3822-3823.

38 Gramsci, Selections From The Prison Notebooks, loc. 10500-10501. 
they serve. In the 20th century it was the consumers who were proletarized and we lost the old knowledge. Proleterization isn't financial poverty, but the loss of knowledge. Consumers do not produce their own way of living, which is now prescribed by the big corporate names." ${ }^{39}$

Although Stiegler's solution sounds vague and not a little utopian - and certainly does not have the "critical" transformational perspective we would expect perhaps from such incisive social and political theorizing - it steers us in a direction from which the broader critique of neoliberalism often shies away.

The crisis of neoliberal hegemony comes down to a crisis of liberal democracy stemming from the crisis of representation that can be tracked all the way back to the end of the Aufklärung. It is a hollowing out of the political, caused by the passage of dialectic into a highly undialectical planetary economism of algebrarically codified and commodified desire. The same process is spurred on by the sophisms of marketing (in contradistinction to the production of exchange values on the market itself), where the sublimation of drives in the traditional Weberian analysis is transmuted into what Herbert Marcuse called "repressive desublimation", according to which "the progress of technological rationality is liquidating the oppositional and transcending elements in the "higher culture."40

The fundamental challenge of the new era is to recapture the sense of "real presence" in both our language in our social relations, and in our politics.

\section{References}

Adorno, Theodor / Horkheimer, Max: Dialectic of Enlightenment, Philosophical Fragments, trans. Edmund Jephcott, Stanford CA: Stanford University Press, 2002.

Agamben, Giorgio: The Kingdom and the Glory: For a Theological Genealogy of Economy and Government, trans. Lorenzo Chiesa and Matteo Mandarini, Stanford CA: Stanford University Press, Kindle Edition, 2011.

Brown, Wendy: Undoing the Demos: Neoliberalism's Stealth Revolution, New York: Zone Books, 2015.

Cain, Andrew: The Power of Religion in Late Antiquity, New York: Routledge, 2009. Derrida, Jacques: The Beast and the Sovereign, trans. Geoffrey Bennington, vol. ii, Chicago: University of Chicago Press, 2011.

Flynn, Jeffrey: "Communicative Power in Habermas' Theory of Democracy", in: European Journal of Political Theory 3(4).

Foucault, Michel: Power/Knowledge: Selected Interviews And Other Writings, New York: Vintage, 1980.

Goodchild, Philip: Theology of Money, Durham NC: Duke University Press, 2009.

39 Mariannetranslates, Bernard Stiegler and the Economy of Contribution.

40 Herbert Marcuse, One-Dimensional Man (London: Sphere Books, 1968), 75. 
Goux, Jean-Joseph: Symbolic Economies: After Marx and Freud, Ithaca, NY: Columbia University Press, 1990.

Gramsci, Antonio: Further Selections From The Prison Notebooks, Minneapolis MN: University of Minnesota Press, 2015, Kindle edition.

Gramsci, Antonio: Selections From The Prison Notebooks, New York: International Publishers, 1992, Kindle edition.

Habermas, Jürgen: Between Facts and Norms: Contributions to a Discourse Theory of Law and Democracy, tr. William Rehg, Cambridge, MA: MIT Press, 1996.

Lashier, Jackson J.: The Trinitarian Theology of Irenaeus of Lyons, unpublished doctoral dissertation, Marquette University, May 2011.

Lazzarato, Maurizio: "Immaterial Labor" in: Radical Thought in Italy: A Potential Politics, ed. Paolo Virno and Michael Hardt, Minneapolis MN: University of Minnesota Press, 2006.

Leshem, Dotan: The Origins of Neoliberalism: Modelling the Economy from Jesus to Foucault, New York: Columbia University Press, 2016.

Marcuse, Herbert: One-Dimensional Man, London: Sphere Books, 1968, 75.

Marx, Karl: Capital, Book 1, 6.

Plato: Phaedrus.

Plato: Republic.

Raschke, Carl: Force of God, New York: Columbia University Press, 2015.

Rives, James B.: Religion in the Roman Empire, Hoboken NJ: Wiley-Blackwell, 2006.

Rousseau, Jean-Jacques: The Works of Jean-Jacques Rousseau: The Social Contract, Confessions, Emile, and Other Essays, Baltimore MD: Common Knowledge Publishers, 2004, Kindle Edition, locations.

Singh, Devin: Divine Currency: The Theological Power of Money in the West, Stanford CA: Stanford University Press, 2018.

Stiegler, Bernard: For A New Critique of Political Economy, trans. David Ross, New York: Polity, 2010.

Stiegler, Bernard: States of Shock: Stupidity and Knowledge in the 21st Century, Hoboken NJ: Wiley Blackwell, 2015, Kindle edition.

\section{Internet Sources}

Mariannetranslates: Bernard Stiegler and the Economy of Contribution, https://ma riannetranslates.wordpress.com/2013/01/04/bernard-Stiegler-and-the-economy-ofcontribution/ [accessed June 20 ${ }^{\text {th }}, 2017$ ], English translation from the French interview: Les gens consomment plus parce qu'ils idéalisent de moins en moins, http://www. fondation-macif.org/bernard-stiegler-les-gens-consomment-plus-parce-quils-ideal isent-de-moins-en-moins [June 20 ${ }^{\text {th }}, 2017$ ].

Rensin, Emmett: The Blathering Superego at the End of History, Los Angeles Review of Books, https://lareviewofbooks.org/article/the-blathering-superego-at-the-end-of-his tory/\#, [June 19 $\left.{ }^{\text {th }}, 2017\right]$.

Carl Raschke, College of Arts, Humanities \& Social Sciences, Department of Religious Studies, University of Denver, Denver CO 80208, USA, e-mail: carlraschke@gmail.com 
Citation: Raschke, Carl: "The Kingdom, the Power, the Glory, and the Tawdry: Neoliberal Hegemony and the "Undoing" of the Demos", in: Appel, Kurt / Raschke, Carl (eds.): The Crisis of Representation (J-RaT 2018 / 2) pp. 40-61.

Datum der Publikation: 21.01.2019 